\title{
Nano-Porous Zirconia Membranes for Separation of Hydrogen from Carbon Dioxide
}

\author{
Sajid H. Shah ${ }^{1 *}$, Raza Mirza², Tayyab Ashfaq Butt ${ }^{2}$, M. Bilal ${ }^{1}$, M.S.A Yasser ${ }^{4}$, Atif Ali ${ }^{4}$, \\ M. Arif Ali ${ }^{5}$, Ayesha Baig ${ }^{7}$, Rida Z. Shah ${ }^{4}$, Mujahid H. Shah ${ }^{6}$, Bilal A. Zafar Amin 1,8**, \\ M. Hassham H. Bin Asad ${ }^{4}$, M. Saqib ${ }^{1}$, Ahson J. Shaikh ${ }^{3}$ \\ ${ }^{1}$ Department of Environmental Sciences, COMSATS University Islamabad Abbottabad Campus, Pakistan \\ ${ }^{2}$ Department of Civil Engineering, University of Hail, Hail Province, Saudi Arabia \\ ${ }^{3}$ Department of Chemistry, COMSATS University Islamabad, Abbottabad Campus Pakistan \\ ${ }^{4}$ Department of Pharmacy, COMSATS University Islamabad, Abbottabad Campus Pakistan \\ ${ }^{5}$ Department of Soil Science, Bahauddin Zakariya University Multan, Pakistan \\ ${ }^{6}$ Department of Geology, XI'an Shiyon, University of China \\ ${ }^{7}$ Department of Biotechnology, COMSATS University Islamabad Abbottabad Campus, Pakistan \\ ${ }^{8}$ Energy Research Center, COMSATS University Islamabad, Lahore Campus
}

Received: 11 April 2020

Accepted: 8 September 2020

\begin{abstract}
A defect free nano-porous zirconia membrane was fabricated using sol-gel method for the separation of $\mathrm{H}_{2}$ gas from a mixture of $\mathrm{H}_{2}$ and $\mathrm{CO}_{2}$. Agglomeration of sol was controlled by releasing hydrolyzing water slowly by the reaction of solvent such as alcohol and acetic acid unlike conventional technique. FE-SEM image of ten times coated membrane showed a uniform zirconia layer of $885 \mathrm{~nm}$ thickness, coated on $\alpha-\mathrm{Al}_{2} \mathrm{O}_{3}$ support. The membrane had pore size of $6 \mathrm{~nm}$. Membrane was fired at 400, 450, and $500^{\circ} \mathrm{C}$ to remove organic content, to estimate the final calcination temperature. XRD study confirmed that the zirconia was transformed into tetragonal phase. The crystallite size (D) was 5.0, 10.13, and $16.28 \mathrm{~nm}$ for dried and calcined zirconia powder respectively, at 25,400 and $500^{\circ} \mathrm{C}$. Scherrer's equation was used to estimate crystallite size. TGA showed that there was no significant loss of mass above $600^{\circ} \mathrm{C}$. Gas permeance of the supported $\mathrm{ZrO}_{2}$ layers was studied by the development of laboratory scale gas permeation setup. The permeance for $\mathrm{H}_{2}$ and $\mathrm{CO}_{2}$ as single component at $300^{\circ} \mathrm{C}$, respectively, was $15.21 \times 10^{-6}$ and $2.0 \times 10^{-6} \mathrm{~mol} /\left(\mathrm{m}^{2} \mathrm{sPa}\right)$. Permeance of membrane in $75: 25 \mathrm{H}_{2}: \mathrm{CO}_{2}$ binary feed mixture was $9.96 \times 10^{-6}$ and $1.21 \times 10^{-6} \mathrm{~mol} /\left(\mathrm{m}^{2} \mathrm{sPa}\right)$, respectively, at $300{ }^{\circ} \mathrm{C}$. The selectivity of hydrogen over $\mathrm{CO}_{2}$ in $\mathrm{ZrO}_{2}$ membrane for $75: 25 \mathrm{H}_{2} / \mathrm{CO}_{2}$ binary feed mixture was 8.23 . These results demonstrated that the membranes offer high potential for purification of hydrogen and carbon dioxide in a mixture at an elevated temperature.
\end{abstract}

Keywords: zirconia, gas permeation, synthesis conditions, esterification, calcination, nano-structure

\footnotetext{
*e-mail: sajid512@cuiatd.edu.pk

**e-mail: Drbilalamin@cuilahore.edu.pk
} 


\section{Introduction}

Recently inorganic ceramic membranes have drawn great attraction recently due to their good gas separation and purification characteristics, low energy cost, ease of operation, high energy efficiency, hydrothermal, mechanical and chemical stability, and durability [1-4]. Porous inorganic ceramic membranes such as $\mathrm{Al}_{2} \mathrm{O}_{3}, \mathrm{SiO}_{2}, \mathrm{TiO}_{2}$ and $\mathrm{ZrO}_{2}$ etc. or a combination of these materials have great potential for gas permeation and liquid separation at an elevated temperature and separation in aggressive media that is difficult to achieve using commercial polymer membranes [5-7]. These membranes find many applications such as environment, medical, chemical engineering, food production and petro-chemical industrial processes. These membrane usually consist of three layers such as macroporous support, mesoporous intermediate layers and top separation layer [8-9].

Among membranes, the conventional silica based membranes with pore size less than $1 \mathrm{~nm}$ imparts good gas separation performance at higher temperature up to $600^{\circ} \mathrm{C}[10]$ in dry atmosphere. However, the major challenge posed by these membranes is their hydrophilic property. These membranes contain hydrophilic silanol groups and these group are vulnerable to react with moisture at an elevated temperature, causing densification of the membrane and ultimately damaging the pore structure and effect the separation performance such as selectivity and permeance. Many strategies have been considered to improve silica membrane, but hydrothermal stability is still the major challenge to be solved [11].

Other ceramic materials such as zirconia and titania were proposed to use for gas and liquid separation in the presence of steam at an elevated temperatures. [12]. Zirconia offers more chemical stability in comparison with gamma alumina and titania. These membranes have high potential to separate gases and liquid at an elevated temperature and exhibit alkali durability and stability. It is usually fabricated by using sol-gel techniques and coated on mesoporous intermediate layer. Mesoporous layer is further coated on macroporous support and pore size can be tune by controlling synthesis parameters [1315]. Zirconia is used for multiple applications such as membrane separation, adsorption, sensors, solar cell as light absorption layer, pharmaceuticals, catalyst, and catalysts support [16-23].

Although zirconia is very promising material, but there are two obstacles which needs to be addressed. Firstly, the instability of the sol due to its fast hydrolysis in comparison with condensation reaction. Secondly, phases change at certain temperature that results into the cracking of the material due to stress development. Many researcher reported various strategies to slow down hydrolysis reaction that develops precipitations or agglomerations of the zirconia particles and to improve thermal stability at higher temperatures. Nitric acid was used as peptizing agent. Yttria was incorporated into the zirconia matrix to improve the thermal stability of the material. Use of acetic acid and acetylacetone were also reported by many researcher to reduce hydrolysis rate of zirconia [24, 25]. Suleiman et al. [26] reported an improved $\mathrm{SiO}_{2}-\mathrm{ZrO}_{2}$ sol and the sol was further modified by using acetylacetone. Membrane showed high hydrogen performance of $10 \times 10^{-7} \mathrm{~mol} \mathrm{~m}^{-2} \mathrm{~s}^{-1} \mathrm{~Pa}^{-1}$ with $\mathrm{H}_{2}: \mathrm{SF}_{6}$ permselectivity of 7600 at $300^{\circ} \mathrm{C}$.

Silva and Vasconcelos [27] developed zirconia using hydrolysis and condensation process. They studied the effects of molar ratios of concentrations of $\mathrm{H}_{2} \mathrm{O}$ on zirconia structure. Higher molar ratio of water favored the increase of pore diameter and surface area. The results demonstrated that the suitable calcination temperature was $400^{\circ} \mathrm{C}$ and there was a complete burn out of organic material at $330^{\circ} \mathrm{C}$.

Shuang et al [28] developed defect free zirconia membrane by sol gel method by using $\mathrm{SiC}$ support to enhance thermal and chemical stability. However, the pore size from 4.5-6.0 $\mu \mathrm{m}$ of the support was too large to hold mesoporous zirconia.

In spite of excellent efforts made to improve the stability of the sol, tuning pore size and microstructure stability remained as one of the major challenges in comparison with other ceramic materials. In this study, defect free nano-porous zirconia membrane was fabricated to separate hydrogen from $\mathrm{CO}_{2}$ using sol-gel method. Thin porous zirconia membrane was coated on $\alpha$-alumina support. The resulting membrane was characterized to evaluate surface morphology and perpendicular membrane cross section, gradual mass loss, and performance. Agglomeration of sol was controlled by releasing hydrolyzing water slowly by the reaction of solvent such as alcohol and acetic acid unlike conventional technique. The influence of synthesis parameters such as drying procedures, calcination programme on microstructure and performance of porous zirconia membranes were investigated. The effect of temperature on membrane performance was discussed.

\section{Materials and Methods}

\section{Membranes Fabrication}

Fig. 1a) shows the fabrication of sol-gel derived zirconia membranes using zirconium propoxide (SigmaAldrich) solution as precursor. Zirconium propoxide solution was dissolved in 1-propanol with the molar ratios of each 0.01 and 0.04 , respectively. Then glacial acetic acid (R \& M Marketing, Essex, UK), was added with molar ratio of 0.04 . The solution was stirred for 3-4 h until it became cloudy with $\mathrm{pH}$ value of five. Nitric acid $\left(\mathrm{HNO}_{3}\right), 65 \%$, Merck, Germany, was added as peptizing agent to prepare stable sol and to avoid agglomeration. The solution was turned clear again with $\mathrm{pH}$ value of 1 . 


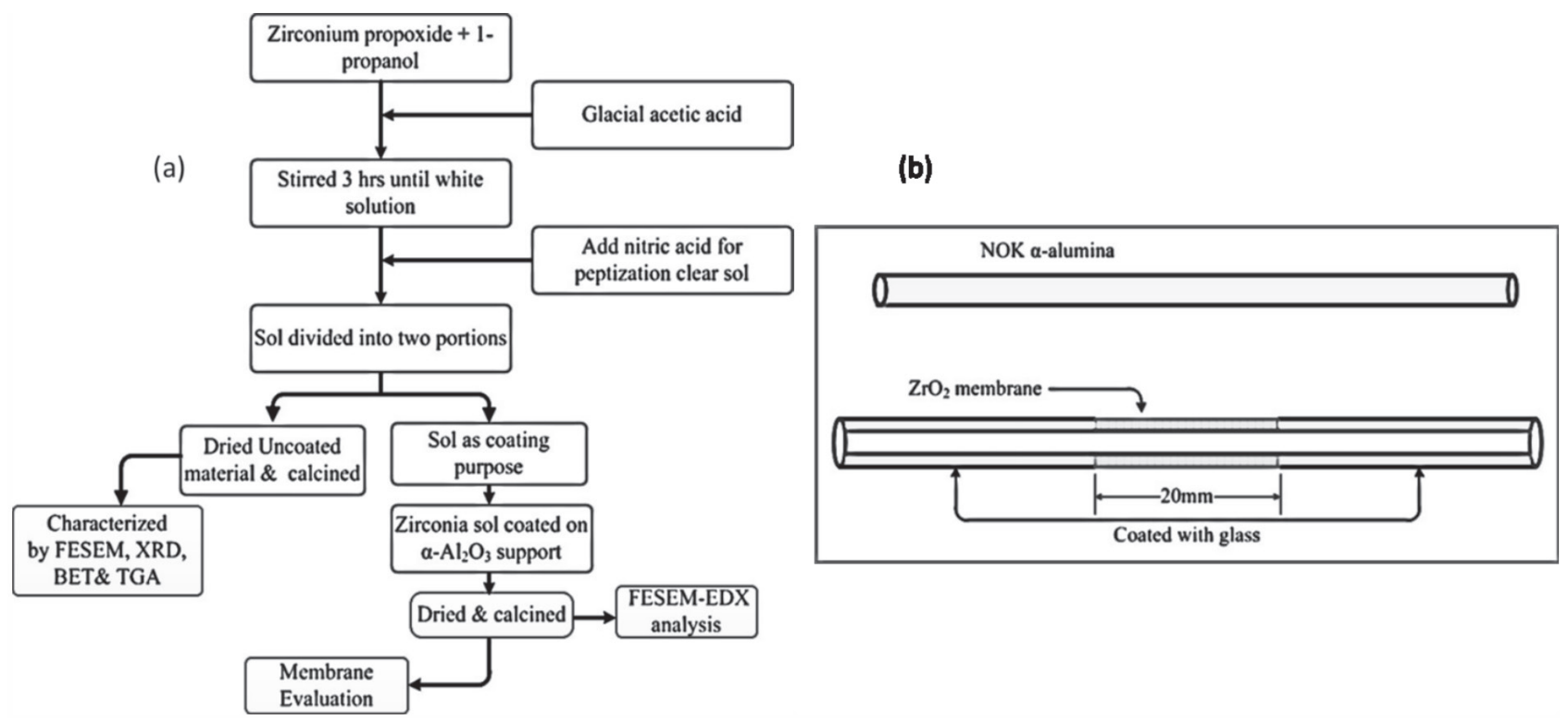

Fig. 1. a) Synthesis procedure for zirconia membrane, b) $\mathrm{ZrO}_{2}$ membrane coated on $\alpha$-alumina support.

Fig. 1b) shows synthesis of zirconia sol and the coating procedure of zirconia and glass sealant on $\alpha-\mathrm{Al}_{2} \mathrm{O}_{3}$ tubular support. $\mathrm{ZrO}_{2}$ membrane was coated on $\alpha$-alumina macroporous support. One portion of the zirconia sol was dip coated on $\alpha-\mathrm{Al}_{2} \mathrm{O}_{3}$ tubular support (supplied by NOK Co., Japan). Average pore size of the tubular support was 110-180 nm. Porosity of the support was 0.42-0.55. Except for central part, a special glass sealant, GA-13 (provided by NEG Co) was used to coat the support. Then zirconia was coated on the support. Both coated and uncoated zirconia were dried and calcined. Dipping, drying and calcination were repeated for ten times. Drying was carried out till $70^{\circ} \mathrm{C}$ in a humidity and temperature control oven. The dried coated and uncoated membranes were calcined in a furnace with heating and cooling rate of $0.5^{\circ} \mathrm{C} \mathrm{min}^{-1}$ from room temperature to $200^{\circ} \mathrm{C}$, then $1^{\circ} \mathrm{C} \mathrm{min}-1$ to $500^{\circ} \mathrm{C}$ for 1 hour. The membranes were also calcined at higher heating and cooling rate of $10^{\circ} \mathrm{C} \mathrm{min}{ }^{-1}$ from room temperature to $500^{\circ} \mathrm{C}$ for 1 hour to know the influence of heating rate on membrane morphology.

\section{Membranes Characterization}

Membrane surface morphology and thickness was studied by adopting 55VP FESEM. Suitable characterization method to predict surface area, pore size distribution, pore size, and adsorption-desorption isotherm was chosen as Brunauer-Emmett-Teller (BET), Micromertics ASAP 2020 sorptometer apparatus equipped with two independent vacuum systems. To predict elemental composition of the material, EDX (Oxford INCA 400) was opted. XRD (D-8Bruker) was used to determine particle size, phase change and thermal stability. Characterization of thermochemical properties and calcination temperature was investigated using thermogravimetric method (TGA-7 instruments).
Scherrer's Equation 1 was used to estimate crystallite size.

$$
D=\frac{0.89 \lambda}{B \operatorname{Cos} \theta}
$$

\section{Gas Permeation Measurement}

Various approaches have been adopted by various researchers to calculate the performance of the membranes for gas separation. Kusakabe et al. [29] and Kim et al. [30] calculated the permeance of the membranes by using Equation 2. Fig. 2 shows gas permeation setup, and schematic illustration of gas permeation vessel. Permeation of both single, and binary gas mixture $\left(\mathrm{H}_{2}\right.$ and $\left.\mathrm{CO}_{2}\right)$ through zirconia membrane was carried out at 25,150 and $300^{\circ} \mathrm{C}$, respectively. $\mathrm{H}_{2}$ and $\mathrm{CO}_{2}$ were passed from outside of the membrane and argon as sweep gas was passed from inner part of the membrane layer at ambient pressure throughout the experiment. Single $\mathrm{H}_{2}$ and $\mathrm{CO}_{2}$ gas was $80 \mathrm{ml} / \mathrm{min}$ and for sweep gas was $20 \mathrm{ml} / \mathrm{min}$, (flow rate), respectively. Flow rate in the feed side for $60: 40 \mathrm{H}_{2}: \mathrm{CO}_{2}$ was 48 and $32 \mathrm{ml} / \mathrm{min}$ for $75: 25 \mathrm{H}_{2}: \mathrm{CO}_{2}$ mixture was 60 and $20 \mathrm{ml} / \mathrm{min}$, respectively. Flow rate of single and binary mixture were measured using bubble flow meter at the exit. Gas chromatograph-TCD (Shimadzu, GC-8A) was used to calculate the composition of gas.

Permeance was calculated by using following formula [29, 30]:

$$
P=\frac{\text { mole permeated per unit time }}{(\text { membrane area })(\text { partial pressure difference })}
$$

Ideal $\left(\alpha_{\mathrm{i}}\right)$ and binary $\left(\alpha_{\mathrm{m}}\right)$ selectivities of $\mathrm{H}_{2}$ over $\mathrm{CO}_{2}$ [31-33] were determined using the following expression. 

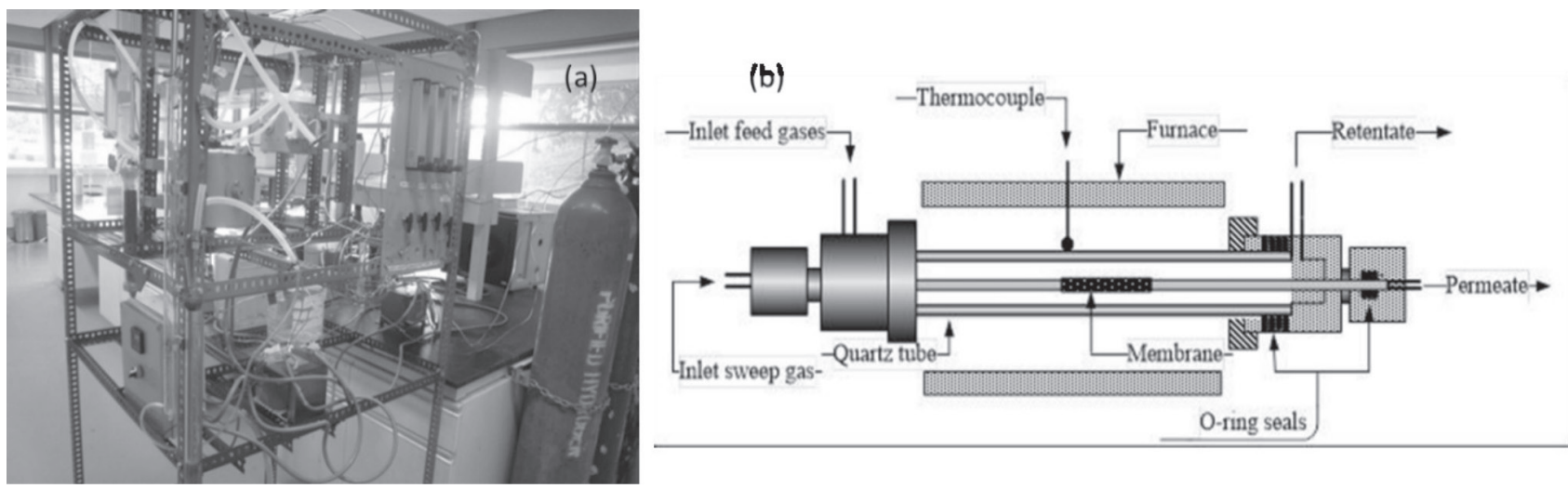

Fig. 2. a) Gas permeation setup, b) schematic illustration of gas permeation vessel.

$$
\begin{gathered}
\propto_{i}=\frac{P_{a}, \text { single }}{P_{b}, \text { single }} \\
\propto_{m}=\frac{P_{a}, \text { binary }}{P_{b}, \text { binary }}
\end{gathered}
$$

\section{Results and Discussions}

\section{Effect of Synthesis Condition on Zirconia Sol Stability and Structure}

The synthesis procedure for stable $\mathrm{ZrO}_{2}$ sol was optimized. Stable sol is vital to prepare membrane of desirable permeation and selectivity. Many researchers such as Chang et al. [34] reported important factors influencing sol stability through controlled hydrolysis of zirconia sol includes hydrolysis conditions $\mathrm{H}_{2} \mathrm{O}$ / $\mathrm{Zr}$, Alcohol/Zr, acid/Zr and Acid/Alcohol molar ratios, peptization conditions, phase stabilizers, type and the amount of chelating agent used to modify reaction rate. Difficulty of synthesizing zirconia sol is related to its fast hydrolysis. Rapid hydrolysis can be controlled via esterification of alcohol and acid that releases water slowly. Chang et al. [34] reported that $\gamma-\mathrm{Al}_{2} \mathrm{O}_{3}$ and titania sol can easily be synthesized compared to zirconia. Since zirconia precursor reacts with water rapidly due its fast hydrolysis than condensation. Esterification can controlled the release of water for hydrolysis [35, 36]. Okubo et al. [37] reported that if hydrolysis is faster than condensation, then agglomeration of zirconia sol takes place due to precipitation. In this work, water was not used directly to hydrolyze zirconium alkoxide unlike conventional method for the synthesis of zirconia sol. First reaction which can release the hydrolyzing water by the reaction of acid and alcohol. Water was released in the condensation or oxolation reaction. Macromolecular species of zirconia was formed during sol gel process that consists of $\mathrm{Zr}-\mathrm{O}-\mathrm{Zr}$ bond in propanol solution.

The zirconia sol with medium viscosity was optimized by using low molar ratios of zirconia precursor. Zirconium propoxide solution was dissolved in 1-propanol with the molar ratios of 0.01 and 0.04 , respectively. Then glacial acetic acid was added with molar ratio of $0.04 . \mathrm{HNO}_{3}$ acid was used to control agglomeration of sol for its stability. It was reported by [38] that due to using $\mathrm{HNO}_{3}$, compact structure of sol was produced due to repulsion of sol particles which avoids agglomeration of sol and consequently stable sol was formed otherwise defect are produced in the membrane due to agglomeration and loose structure. Zirconia sol was dried in the drying oven under controlled humidity and temperature (relative humidity $35-45 \%$, temperature $70^{\circ} \mathrm{C}$ ). Sol remained sticky when it was dried in open air. Absorption of water from air might had caused reversible reaction and difficulties in sol drying. Membrane dip coating time of 30 seconds and pulling rate of $5 \mathrm{~mm} / \mathrm{min}$ was optimized. Calcination was performed with heating and cooling rate of $0.5^{\circ} \mathrm{C} \mathrm{min}^{-1}$ from room temperature to $200^{\circ} \mathrm{C}$, then $1^{\circ} \mathrm{C} \min ^{-1}$ to $500^{\circ} \mathrm{C}$ for $1 \mathrm{~h}$. This temperature scheme resulted into the smooth surface morphology without producing cracks as shown by SEM image in Fig. 3e). The higher heating and cooling rate of $10^{\circ} \mathrm{C} \mathrm{min}{ }^{-1}$ from room temperature to $500^{\circ} \mathrm{C}$ for 1 hour, resulted cracks on the surface of the coated zirconia sol as shown in Fig. 4a), and b).

\section{Membrane Characterization}

Fig. 3 (a-b) shows SEM photograph of an $\alpha-\mathrm{Al}_{2} \mathrm{O}_{3}$ tubular substrate support which was used to coat zirconia membrane. Fig. 3 (c-d) presents FESEM photograph of one and three times coated $\mathrm{ZrO}_{2}$ membrane on alumina tubular support and Fig. 3e) shows FE-SEM photograph of ten times coated $\mathrm{ZrO}_{2}$ on tubular support when proper calcination programme was followed. Ten times coated membranes on support seemed to be homogenous, smooth and crack free. Fig. 3f) presents EDX photograph of three times deposited $\mathrm{ZrO}_{2}$ membrane on tubular support. Spectrum 1 shows 25 wt. \% of zirconia coated on support. Fig. 4 (a-b) displays uncontrolled calcination temperature that resulted into the cracks on the surface. 

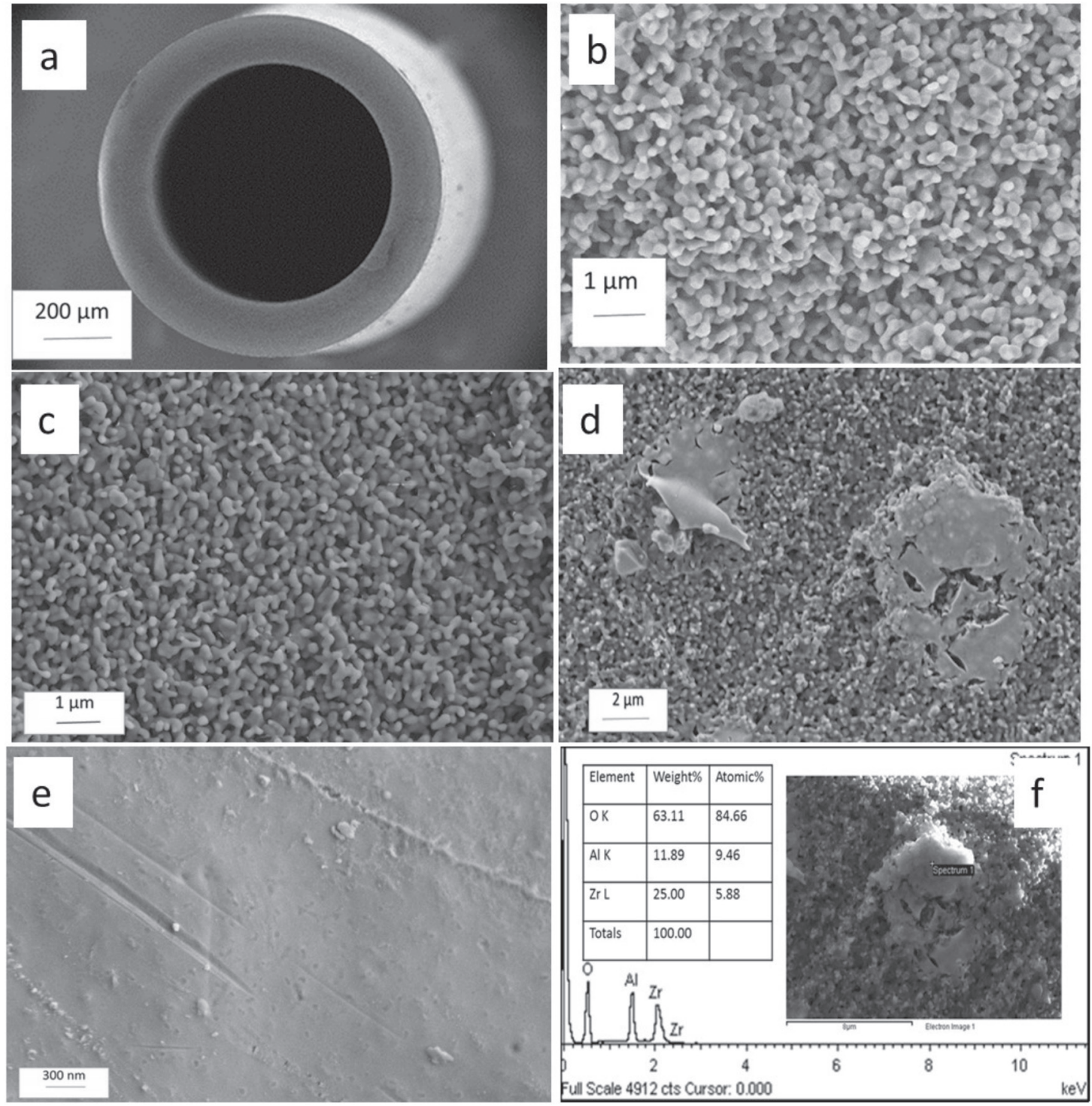

Fig. 3 a) SEM photograph of an alumina tubular support, b) SEM photograph of an $\alpha-\mathrm{Al}_{2} \mathrm{O}_{3}$ tubular substrate c) FE-SEM photograph of one time coated $\mathrm{ZrO}_{2}$ membrane on alumina tubular, d) SEM photograph of surface morphology of three times deposited $\mathrm{ZrO}_{2}$ membrane on alumina tubular support, e) FE-SEM photograph of surface morphology of ten times coated $\mathrm{ZrO}$ on tubular support with proper calcination programme, f) EDX photograph of surface morphology of three times deposited $\mathrm{ZrO}_{2}$ membrane on alumina tubular support.

Fig. 5 (a-b) and c). displays SEM image of initial to final steps of cross section of $\mathrm{ZrO}_{2}$ membrane coated on alumina tubular support. Fig. 5c) shows SEM photograph thickness of ten times coated $\mathrm{ZrO}_{2}$ on macroporous $\mathrm{Al}_{2} \mathrm{O}_{3}$ tubular with thickness of $885 \mathrm{~nm}$.

TGA was carried out in order to investigate suitable calcination temperature for $\mathrm{ZrO}_{2}$ gel. Fig. 6a) displays the TGA outcome of dried $\mathrm{ZrO}_{2}$ powder. The mass loss before $120^{\circ} \mathrm{C}$ might be attributed to the evaporation of adsorbed water and the solvent. This mass loss was more than $15 \%$. At 120 to $360^{\circ} \mathrm{C}$, the weight loss was more than $43 \%$ of the total. This could be assigned to the release of nitro-compounds. Similar results were reported by $\mathrm{Wu}$ et al. [36] in which they display that the nitro-compounds were oxidized at $160^{\circ} \mathrm{C}$. Weight loss from 360 to $600^{\circ} \mathrm{C}$ was almost $6 \%$ and this was due to loss of organic compounds. Above $600^{\circ} \mathrm{C}$, there was no gradual loss of mass. Seung-Goo Kim et al. [39] reported similar result supporting present works. Combustion of organic compounds was observed [36] at $360-500^{\circ} \mathrm{C}$. Thus suitable calcination temperature was determined to be $600{ }^{\circ} \mathrm{C}$, since there was no mass loss below this temperature.

Fig. 6b) depicts XRD spectrum of unsupported $\mathrm{ZrO}_{2}$ gel before (a) and after calcination (b, c, d) at 400, 450 and $500^{\circ} \mathrm{C}$. Scherrer's equation was used to calculate crystallite size. The Bragg angles $(2 \theta)$ were $25.7^{\circ}, 30.4^{\circ}$, $30.5^{\circ}$ and $30.5^{\circ}$ and $\mathrm{B}$ (calibrated width of diffraction) were $1.6^{\circ}, 0.8^{\circ}, 0.5^{\circ}$, and $0.5^{\circ}$ for zirconia gel. X-ray wavelength $(\lambda)$ was taken as $0.154 \mathrm{~nm}$ and the value for constant (k) was 0.98 . Crystallite size (D) of zirconia was 5.0, 10.13, and $16.28 \mathrm{~nm}$ for the zirconia powder of the dried and calcined zirconia at 400,450 and $500^{\circ} \mathrm{C}$, respectively. Crystallite size at $400,450^{\circ} \mathrm{C}$ was smaller 

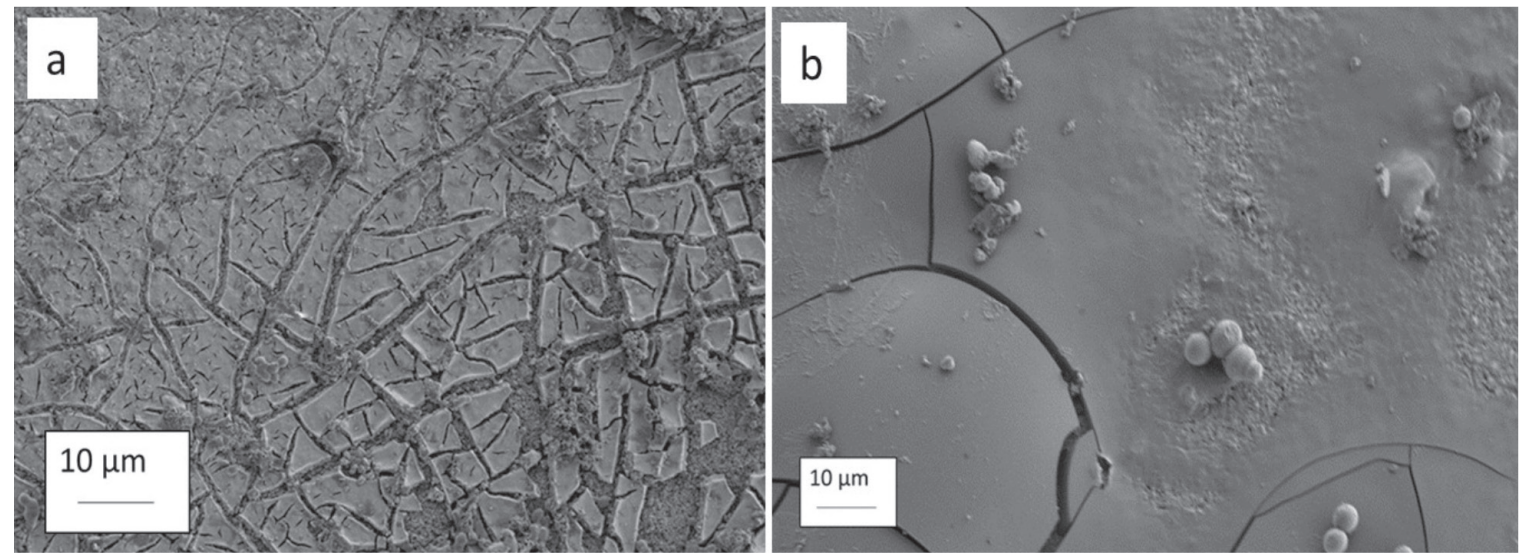

Fig. 4. a), b) FE-SEM photograph of surface morphology of ten times coated $\mathrm{ZrO}_{2}$ on tubular support with unsuitable calcination programme.

than 6.8 and 12.23 reported by Sajid et al. [25] for YSZ. Kim et al. [30] investigated $20.8 \mathrm{~nm}$ crystalline size at calcination temperature of $450^{\circ} \mathrm{C}$. Larger crystallite size $[25,30]$ was possibly due to incorporation of yttria in zirconia matrix. As the calcination temperature increased, the crystallite size increased. This behaviour resulted into the sharpness of the peak. Shi et al. [40] also reported this kind of trend. Crystalline phase developed from amorphous form as the calcination temperature increased. Amorphous zirconia membrane gel JCPDS file no. 32-1494 (Q) was transformed to tetragonal phase indicated by the JCPDS file no. 81-1544 (C), 80-2155 (C) at calcination temperature of 400 and $450^{\circ} \mathrm{C}$ and to hexagonal indicated by the JCPDS file no. $48-1637$ at the temperature of $500^{\circ} \mathrm{C}$. Peak positions of calcined zirconia indicate the tetragonal phase of zirconia. Jeffery Chi-Sheng et al. [36] reported that the development of crystalline form from amorphous phase was actually due to sol-gel fabrication technique. Table 1 displays XRD data for dried and calcined unsupported $\mathrm{ZrO}_{2}$ membranes.

Fig. 6c) shows pore size distribution of zirconia sol calcined at $500^{\circ} \mathrm{C}$. Average pore size calculated by BJH is 6.7 and $4.6 \mathrm{~nm}$, respectively. The average pore size by BET method was $6.73 \mathrm{~nm}$ and $6.36 \mathrm{~nm}$ from desorption. Some less than $2 \mathrm{~nm}$ pore were explored by the shape of the curve. However, pore size smaller than $2 \mathrm{~nm}$ cannot be measured from nitrogen adsorptiondesorption isotherm. Fig. 6d) shows the $\mathrm{N}_{2}$ adsorptiondesorption isotherms of $\mathrm{ZrO}_{2}$ calcined at $500^{\circ} \mathrm{C}$. This curve (hysteresis loop) starts shift from 0.32 to 0.8 of the $\left(\mathrm{p} / \mathrm{p}_{\mathrm{o}}\right)$. This isotherm displays broad pore size distribution. Type of the curve (type IV isotherm) depicts the typical behaviour of the mesoporous material. The type of the pores and PSD also confirmed from this type of curve. Broad pore size distribution identifies the presence of microspore, mesoporous and macropores but the type of the curve typically represents the mesoporous nature of the membrane. This shows that most of the pores lie in the range of (mesoporous) $6 \mathrm{~nm}$. Some pores with micropore less than $2 \mathrm{~nm}$ and most of the pores representing narrow pore size distribution lie between 2-50 nm. Permeation results on the basis of the pore size distribution shown in this work are in good agreement with the results reported elsewhere [42, 33, 25] of mesoporous membranes.

\section{Gas Separation Performance of Zirconia Membrane}

To investigate the permeation behaviour of hydrogen and $\mathrm{CO}_{2}$ through zirconia membrane, lab
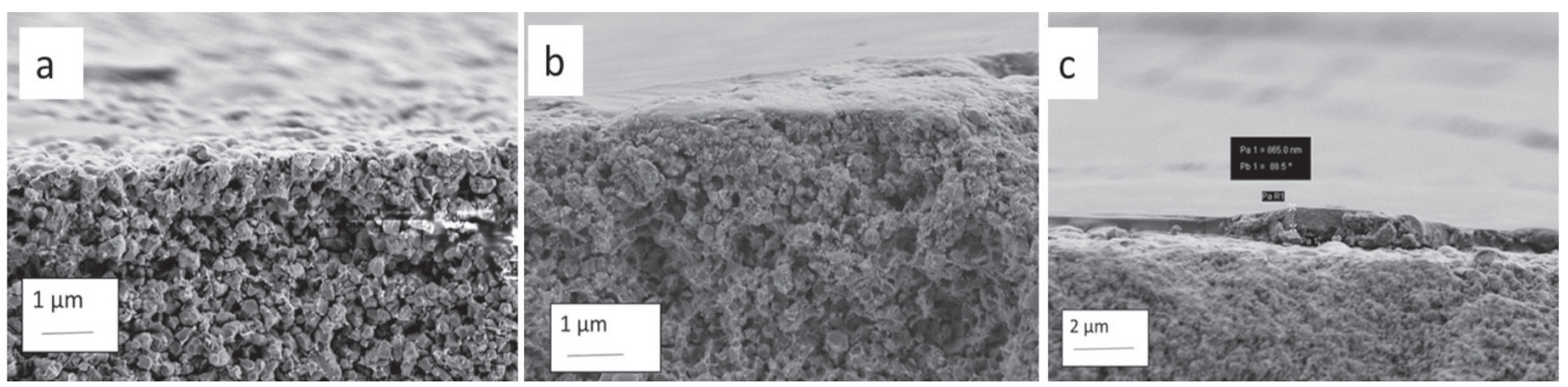

Fig. 5. a), b) FE-SEM photograph of surface morphology coated $\mathrm{ZrO}_{2}$ on tubular support, c) SEM photograph perpendicular cross section of ten times coated $\mathrm{ZrO}_{2}$ on alumina tubular support with thickness of $885 \mathrm{~nm}$. 
Table 1. XRD data for dried and calcined unsupported $\mathrm{ZrO}_{2}$ membranes.

\begin{tabular}{|c|c|c|c|}
\hline Membranes & $\begin{array}{c}\text { Calcination } \\
\text { temperature } \\
{ }^{\circ} \mathrm{C}\end{array}$ & $\begin{array}{c}\text { Crystal } \\
\text { structure }\end{array}$ & $\begin{array}{c}\text { Crystallite } \\
\text { size } \\
(\mathrm{nm}) \text { XRD }\end{array}$ \\
\hline $\mathrm{ZrO}_{2 \mathrm{~d}}$ & Dried & Amorphous & 5.0 \\
\hline $\mathrm{ZrO}_{2 \mathrm{e}}$ & 400 & $\begin{array}{c}\text { Cubic face } \\
\text { centre }\end{array}$ & 10.13 \\
\hline $\mathrm{ZrO}_{2 \mathrm{f}}$ & 500 & $\begin{array}{c}\text { Cubic face } \\
\text { centre }\end{array}$ & 16.28 \\
\hline
\end{tabular}

scale permeation unit was used. Fig. 7 (a, b) and c) presents the permeation behaviour of single gas and binary gas mixture of $75: 25 \mathrm{H}_{2}: \mathrm{CO}_{2}$ and $60: 40 \mathrm{H}_{2}: \mathrm{CO}_{2}$ as function their kinetic diameter at 25, 150, and $300^{\circ} \mathrm{C}$, respectively. Fig. 7 (a, b) and c) shows that the increase or decrease of permeance through $\mathrm{ZrO}_{2}$ membrane adopted pattern of the molecular size of the gases. $\mathrm{H}_{2} \quad(0.289 \mathrm{~nm})$ has smaller kinetic diameter in comparison with $\mathrm{CO}_{2}(0.33 \mathrm{~nm})$. Fig. 7 (a, b) and c), shows that smaller kinetic diameter depicts higher permeance even at same flow rate and molar concentration. According to [41, 25], the decrease or increase in permeance was regulated by the molecular size of the permeant gases.

Fig. $7(a, b)$ and c) shows that the permeance of single component $\mathrm{H}_{2}$ and $\mathrm{CO}_{2}$ is higher than the permeance of binary mixture of $75: 25 \mathrm{H}_{2}: \mathrm{CO}_{2}$ and 60:40 $\mathrm{H}_{2}: \mathrm{CO}_{2}$. This difference was due to higher flow rate i.e $80 \mathrm{ml} / \mathrm{min}$ of each $\mathrm{H}_{2}$ and $\mathrm{CO}_{2}$ as single component gas. The flow rate of $\mathrm{H}_{2}$ and $\mathrm{CO}_{2}$ in the binary mixture of $75: 25 \mathrm{H}_{2}: \mathrm{CO}_{2}$ was 60 and $20 \mathrm{ml} / \mathrm{min}$ and for $60: 40$ $\mathrm{H}_{2}: \mathrm{CO}_{2}$ the flow rate was 48 and $32 \mathrm{ml} / \mathrm{min}$, respectively. Higher flow rate leads to higher concentration of gases and ultimately higher will be the permeance. Similarly, permeance of hydrogen in binary mixture of 75:25 $\mathrm{H}_{2}: \mathrm{CO}_{2}$ was higher than $60: 40 \mathrm{H}_{2}: \mathrm{CO}_{2}$. The selectivity of $\mathrm{H}_{2} / \mathrm{CO}_{2}$ was about 7.64, while, permeance of $\mathrm{H}_{2}$ and $\mathrm{CO}_{2}$ as single component at $300^{\circ} \mathrm{C}$, respectively, was $15.21 \times 10^{-6}$ and $2.0 \times 10^{-6} \mathrm{~mol} /\left(\mathrm{m}^{2} \mathrm{sPa}\right)$. The selectivity of $\mathrm{H}_{2} / \mathrm{CO}_{2}$ in $\mathrm{ZrO}_{2}$ membrane was about 8.23 with $\mathrm{H}_{2}$ and $\mathrm{CO}_{2}$ permeance of $9.96 \times 10^{-6}$ and $1.21 \times 10^{-6} \mathrm{~mol} /\left(\mathrm{m}^{2} \mathrm{sPa}\right)$, respectively for $75: 25$ binary mixture at $300^{\circ} \mathrm{C} . \mathrm{H}_{2} / \mathrm{CO}_{2}$ binary feed mixture.
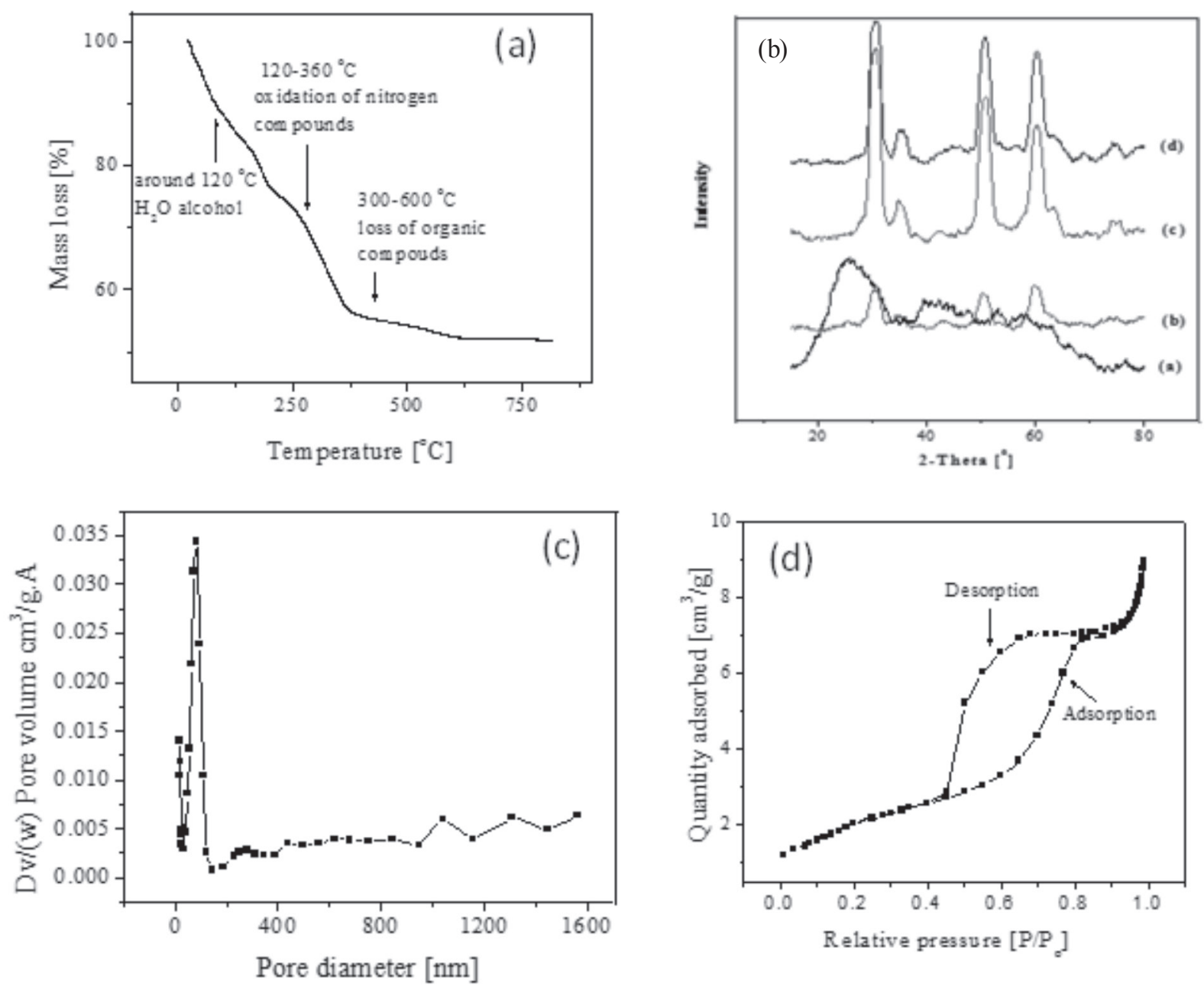

Fig. 6 a) TGA curve of $\mathrm{ZrO}_{2}$ gel, f) XRD pattern of $\mathrm{ZrO}_{2}$ powder dried a) calcined (b, c, d) at 400, 450 and $500^{\circ} \mathrm{C}$, c) PSD of unsupported $\mathrm{ZrO}_{2}$ calcined at $500^{\circ} \mathrm{C}$, d) $\mathrm{N}_{2}$ adsorption-desorption isotherms of $\mathrm{ZrO}_{2}$ calcined at $500^{\circ} \mathrm{C}$ 

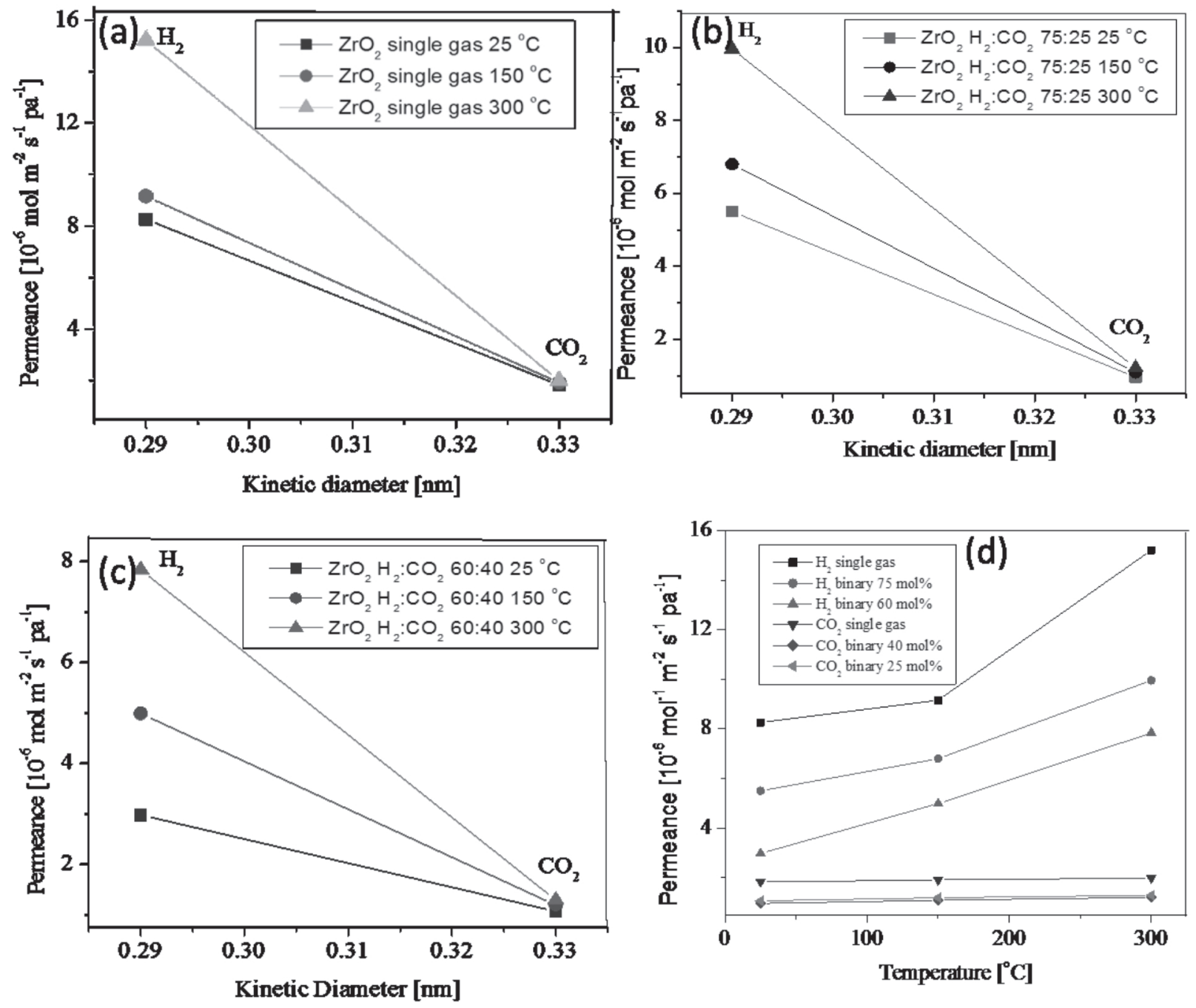

Fig. 7 a) Single gas $\mathrm{H}_{2}$ and $\mathrm{CO}_{2}$ permeance vs kinetic diameter b) Binary gas mixture of $75: 25 \mathrm{H}_{2} / \mathrm{CO}_{2}$ vs kinetic diameter, c) Binary gas mixture of 60:40 $\mathrm{H}_{2} / \mathrm{CO}_{2}$ vs kinetic diameter, d) Single and binary gas mixture permeance vs temperature.

Permeance of $\mathrm{H}_{2}$ and $\mathrm{CO}_{2}$ as single component and binary mixture increased with increasing temperature, while permeance of $\mathrm{CO}_{2}$ remained constant or slightly increased as shown in Fig. 7d). $\mathrm{H}_{2}$ and $\mathrm{CO}_{2}$ permeance were $8.26 \times 10^{-6}, 9.16 \times 10^{-6}, 15.21 \times$ $10^{-6} \mathrm{~mol} /\left(\mathrm{m}^{2} \mathrm{sPa}\right)$, while permeance of $\mathrm{CO}_{2}$ were $1.83 \times$ $10^{-6}, 1.99 \times 10^{-6}$ and $1.91 \times 10^{-6} \mathrm{~mol} \mathrm{~m} \mathrm{~m}^{-2} \mathrm{~s}^{-1} \mathrm{~Pa}^{-1}$, respectively, as single component at permeation temperature of 25 to $300^{\circ} \mathrm{C}$. The permeance values of $\mathrm{H}_{2}$ were $9.96 \times 10^{-6}$ and $7.84 \times 10^{-6} \mathrm{~mol} /\left(\mathrm{m}^{2} \mathrm{sPa}\right)$, at $300{ }^{\circ} \mathrm{C}$, respectively, of binary mixture of $75: 25$ $\mathrm{H}_{2}: \mathrm{CO}_{2}$ and $60: 40 \mathrm{H}_{2}: \mathrm{CO}_{2}$. Binary mixture. Selectivity increased with increasing temperature. These results had close agreement with the reported work of Kusakabe et al. [42]. Pt/YSZ membrane [42] was used to investigate hydrogen performance at various temperatures. Membrane showed $\mathrm{H}_{2} / \mathrm{CO}_{2}$ of about 10 with hydrogen permeance of $5 \times 10^{-6} \mathrm{~mol} /\left(\mathrm{m}^{2} \mathrm{sPa}\right)$ at $300^{\circ} \mathrm{C}$. Increase of permeance followed the increasing pattern of temperature. The permeance [42] was slightly smaller than present work. That might be due to the impregnation of $\mathrm{RhCl} 3 \cdot 3 \mathrm{H}_{2} \mathrm{O}$ or $\mathrm{H}_{2} \mathrm{PtCl}_{6}$ aqueous solution to synthesize $\mathrm{Rh}$ or $\mathrm{Pt}$ loaded $\mathrm{YSZ}$ membrane, resulting into smaller pore size and lower permeance. Both the studies had similarities in term of increase in permeance and selectivities with increasing temperature.

Similar results proposed by Jeffrey Chi-Sheng $\mathrm{Wu}$ et al. [36], that had strong support for present work. Jeffrey Chi-Sheng Wu et al. [36] synthesized crackfree $\mathrm{ZrO}_{2}$ layer for liquid separation using sol-gel technique. They used acetic acid and alcohol to release water slowly to slow down hydrolysis and preventing formation of agglomerations. $\mathrm{HNO}_{3}$ acid was used to peptize the sol and the sol was dried and calcined at firing temperature of $500^{\circ} \mathrm{C}$, which resulted $3.6 \mathrm{~nm}$ average pore size. They found that the permeance of $\mathrm{N}_{2}$ for double coated zirconia membrane was $3.04 \times 10^{-5} \mathrm{~mol} /\left(\mathrm{m}^{2} \mathrm{sPa}\right)$. Authors suggested that solgel derived, defect-free zirconia membrane had great potential for using these membranes in industry significantly. Fig. 8 (a, b) shows that the binary 

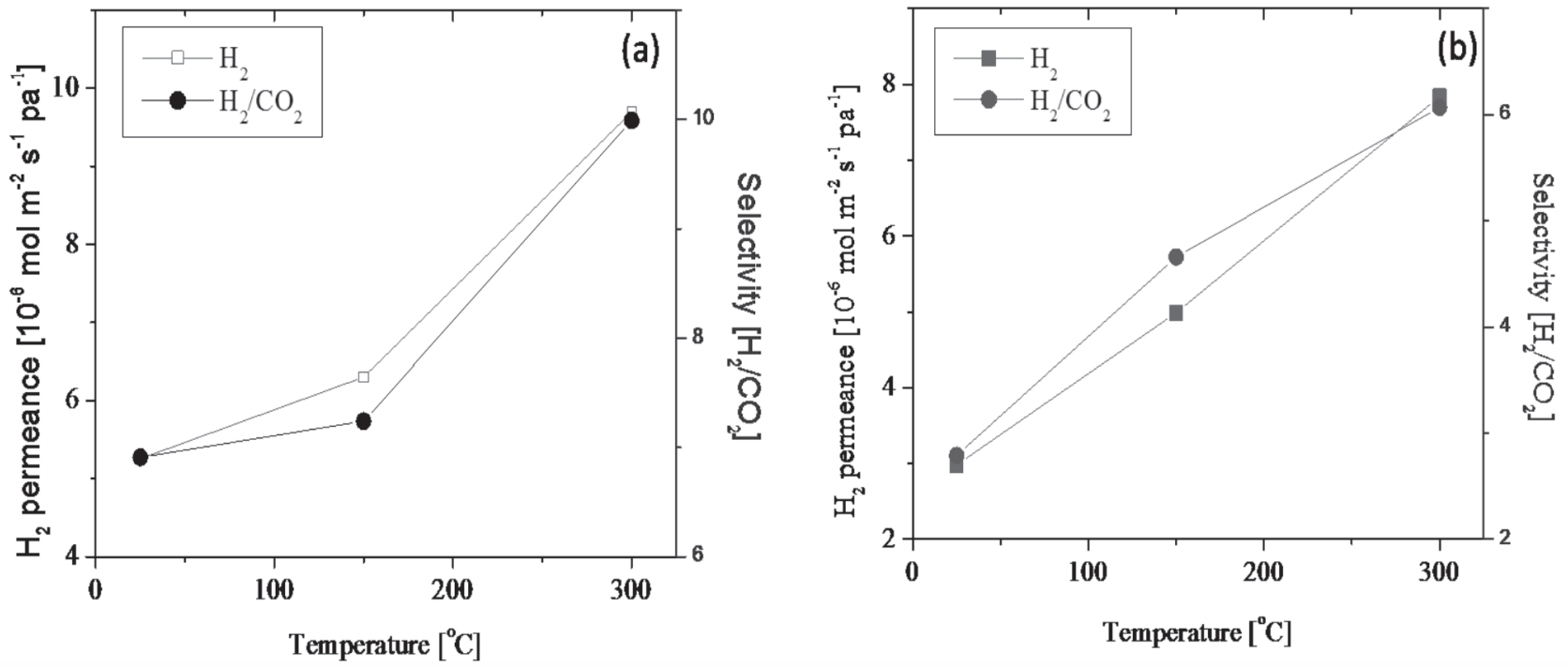

Fig. 8 a) Effect of temperature on selectivity and permeance gases of binary mixture of $75: 25 \mathrm{H}_{2} / \mathrm{CO}_{2}$, and b) of binary mixture of $60: 40$ $\mathrm{H}_{2} / \mathrm{CO}_{2}$.

selectivities for $\mathrm{H}_{2}$ over $\mathrm{CO}_{2}$ were 8.23 and 6.07, respectively, at permeation temperature of $300^{\circ} \mathrm{C}$. Selectivities increased with increasing temperatures. These results are in good agreement with the results reported elsewhere [42, 33, 25]. Sajid et al. [25] investigated that the gas permeance of single component $\left(\mathrm{H}_{2}\right.$ and $\left.\mathrm{CO}_{2}\right)$ was $14.90 \times 10^{-6}, 1.69 \times 10^{-6} \mathrm{~mol} /\left(\mathrm{m}^{2} \mathrm{sPa}\right)$ for $\mathrm{H}_{2}$ and $\mathrm{CO}_{2}$ at $300^{\circ} \mathrm{C}$, respectively. $\mathrm{H}_{2}$ and $\mathrm{CO}_{2}$ permeance through zirconia membranes were $9.7 \times 10^{-6}$ and $0.96 \times 10^{-6} \mathrm{~mol} /\left(\mathrm{m}^{2} \mathrm{sPa}\right)$ of $75: 25 \mathrm{H}_{2}: \mathrm{CO}_{2}$ feed mixture, at permeation temperature of $300^{\circ} \mathrm{C} . \mathrm{H}_{2}$ selectivity over $\mathrm{CO}_{2}$ of zirconia membrane was 10 . The present work had strong support from $\mathrm{Gu}$ et al. [33]. Zirconia membranes were synthesized [33] by sol gel technique using $\alpha-\mathrm{Al}_{2} \mathrm{O}_{3}$ as macroporous support. The membranes were fired at 300, 400, 500 600 and $700^{\circ} \mathrm{C}$, respectively for $1 \mathrm{~h}$. The membranes which were thermally treated at $400^{\circ} \mathrm{C}$ were named as Z400. $\mathrm{H}_{2} \mathrm{SO}_{4}$ solutions with concentrations of $0.10-2.50 \mathrm{~mol} / \mathrm{L}$ for $10 \mathrm{~min}$ were used to modify Z400 membrane. These microporous membranes showed an average pore size of about $2 \mathrm{~nm}$. Authors reported that the permeance of $\mathrm{H}_{2}$ of $0.75 \mathrm{~mol} / \mathrm{L} \mathrm{H}_{2} \mathrm{SO} 4$ modified Z400 was reduced significantly when compared with unmodified Z400. Permeance for all gases changed only slightly for $0.50 \mathrm{~mol} / \mathrm{L} \mathrm{H}_{2} \mathrm{SO}_{4}$ modified $\mathrm{Z} 400$. Membrane showed ideal permselectivity of $\mathrm{H}_{2} / \mathrm{CO}_{2}$ was about $7 . \mathrm{H}_{2}$ permeance was $4.45 \times 10^{-6}$, while the

Table 2. Comparison of $\mathrm{ZrO}_{2}$ performance with other reported work on $\mathrm{ZrO}_{2}$ membranes.

\begin{tabular}{|c|c|c|c|c|c|}
\hline $\begin{array}{l}\text { Membrane } \\
\text { type }\end{array}$ & Support & $\begin{array}{c}\text { System \& } \\
\text { Conc. of } \\
\text { Gases }\end{array}$ & $\begin{array}{l}\text { Permeance of } \mathrm{H}_{2} / \mathrm{CO}_{2} \times 10^{-6} \\
\mathrm{~mol} \mathrm{~m}^{-2} \mathrm{~s}^{-1} \mathrm{~Pa}^{-1}\end{array}$ & $\begin{array}{l}\mathrm{H}_{2} \text { Selectivity } \\
\left(\mathrm{H}_{2} / \mathrm{CO}_{2}\right)\end{array}$ & References. \\
\hline \multirow{3}{*}{$\begin{array}{c}\mathrm{ZrO}_{2} \\
\text { Sol-gel }\end{array}$} & \multirow{3}{*}{$\begin{array}{l}\alpha-\mathrm{Al}_{2} \mathrm{O}_{3} \\
\text { support }\end{array}$} & Single-component gas & \multirow{2}{*}{$15.21 \times 10^{-6}$} & \multirow{3}{*}{7.64 at $300^{\circ} \mathrm{C}$} & \multirow{3}{*}{ Present work } \\
\hline & & $\mathrm{H}_{2}$ & & & \\
\hline & & $\mathrm{CO}_{2}$ & $2.0 \times 10^{-6}$ & & \\
\hline \multirow{3}{*}{$\begin{array}{c}\mathrm{ZrO}_{2} \\
\text { Sol-gel }\end{array}$} & \multirow{3}{*}{$\begin{array}{l}\alpha-\mathrm{Al}_{2} \mathrm{O}_{3} \\
\text { support }\end{array}$} & Binary mixture & & \multirow{3}{*}{8.23 at $300^{\circ} \mathrm{C}$} & \multirow{3}{*}{ Present work. } \\
\hline & & $\mathrm{H}_{2}$ & $9.96 \times 10^{-6}$ & & \\
\hline & & $\mathrm{CO}_{2}$ & $1.21 \times 10^{-6}$ & & \\
\hline \multirow{2}{*}{$\begin{array}{c}\text { YSZ } \\
\text { Sol-gel }\end{array}$} & \multirow{2}{*}{$\begin{array}{c}\alpha-\mathrm{Al}_{2} \mathrm{O}_{3} \\
\text { support }\end{array}$} & Single component $\mathrm{H}_{2}$ & $14.90 \times 10^{-6}$ & \multirow{2}{*}{8.82 at $300^{\circ} \mathrm{C}$} & \multirow{2}{*}[25]{} \\
\hline & & $\mathrm{CO}_{2}$ & $1.69 \times 10^{-6}$ & & \\
\hline \multirow{2}{*}{$\begin{array}{c}\text { YSZ } \\
\text { Sol-gel }\end{array}$} & \multirow{2}{*}{$\begin{array}{c}\alpha-\mathrm{Al}_{2} \mathrm{O}_{3} \\
\text { support }\end{array}$} & Binary mixture $75: 25 \mathrm{H}_{2}: \mathrm{CO}_{2} \mathrm{H}_{2}$ & $9.7 \times 10^{-6}$ & \multirow{2}{*}{10 at $300^{\circ} \mathrm{C}$} & \multirow{2}{*}[25]{} \\
\hline & & $\mathrm{CO}_{2}$ & $0.96 \times 10^{-6}$ & & \\
\hline \multirow{2}{*}{$\begin{array}{c}\mathrm{ZrO}_{2} \\
\text { Sol-gel }\end{array}$} & \multirow{2}{*}{$\begin{array}{c}\alpha-\mathrm{Al}_{2} \mathrm{O}_{3} \\
\text { support }\end{array}$} & $\mathrm{H}_{2}$ & $4.45 \times 10^{-6}$ & \multirow{2}{*}{7 at $34^{\circ} \mathrm{C}$} & \multirow{2}{*}{ [33]. } \\
\hline & & $\mathrm{CO}_{2}$ & $0.39 \times 10^{-6}$ & & \\
\hline
\end{tabular}


permeance of $\mathrm{CO}_{2}$ was $0.39 \times 10^{-6} \mathrm{~mol} /\left(\mathrm{m}^{2} \mathrm{sPa}\right)$ as single component at $34^{\circ} \mathrm{C}$ for zirconia membrane modified with $0.50 \mathrm{~mol} /\left(\mathrm{m}^{2} \mathrm{sPa}\right)$. The lower permeance [33] was due to modification membrane with $\mathrm{H}_{2} \mathrm{SO}_{4}$, with lower pore size. Table 2 presents comparison of $\mathrm{ZrO}_{2}$ performance with other reported $\mathrm{ZrO}_{2}$ membranes. Silva and Vasconcelos [27] developed zirconia using sol-gel technique, while studying the influence of molar ratios of water on zirconia structure. According to [27], higher molar ratio of water favored the increase of pore diameter and surface area. The results demonstrated that the suitable calcination temperature was $400^{\circ} \mathrm{C}$ and complete burn out of organic material took place at $330^{\circ} \mathrm{C}$. Similarly, the work reported by Jinsoo Kim et al. [43] had strong support for the present work. Jinsoo Kim et al. [45] proposed similar results by synthesis and characterization of sol-gel derived yttria stabilized ultrafiltration zirconia membranes and studied their permeation properties. They reported that the crack free supported and unsupported membrane were calcined at $400^{\circ} \mathrm{C}$ and five time dip-coated membrane was about $3 \mu \mathrm{m}$ in thickness, while the pore size was about $3 \mathrm{~nm}$.

\section{Conclusions}

This research demonstrates that a defect free nanoporous zirconia membrane was synthesized by sol-gel technique for the purpose of separating $\mathrm{H}_{2}$ gas from a mixture of $\mathrm{H}_{2}$ and $\mathrm{CO}_{2}$. Zirconia sol was coated on $\alpha-\mathrm{Al}_{2} \mathrm{O}_{3}$ macroporous support. Coated zirconia membrane was dried, calcined, characterized and their performance was investigated by the development of lab scale permeation unit. Permeation of $\mathrm{H}_{2}$ and $\mathrm{CO}_{2}$ as single component and binary mixture of $\mathrm{H}_{2}$ and $\mathrm{CO}_{2}$ was measured at different temperatures. Agglomeration of sol was controlled by releasing hydrolyzing water slowly by the reaction of solvent such as alcohol and acetic acid unlike conventional technique. FESEM image of ten times coated membrane depicted a uniform zirconia layer of $885 \mathrm{~nm}$ thickness on $\mathrm{Al}_{2} \mathrm{O}_{3}$ macroporous support. The pore size observed was around $6 \mathrm{~nm}$. XRD study confirmed that the zirconia was transformed into tetragonal phase. The crystallite size (D) was 5.0, 10.13, and $16.28 \mathrm{~nm}$ for dried and calcined zirconia powder, respectively, at 25, 400 and $500^{\circ} \mathrm{C}$. The study showed that crystallite size increased with increasing calcination temperature. TGA study showed that there was no significant loss of mass above $600{ }^{\circ} \mathrm{C}$. Gas permeance of the supported $\mathrm{ZrO}_{2}$ layers were studied by using laboratory scale gas permeation setup. The membrane showed a $\mathrm{H}_{2} / \mathrm{CO}_{2}$ of about 7.6 with $\mathrm{H}_{2}$ permeance of $15.21 \times 10^{-6}$ and $\mathrm{CO}_{2}$ of $2.0 \times 10^{-6} \mathrm{~mol} /\left(\mathrm{m}^{2} \mathrm{sPa}\right)$ at $300{ }^{\circ} \mathrm{C}$. The selectivity of $\mathrm{H}_{2} / \mathrm{CO}_{2}$ for $275: 25 \mathrm{H}_{2} / \mathrm{CO}_{2}$ binary feed mixture was about 8.23 with permeance of hydrogen of 75:25 $\mathrm{H}_{2} / \mathrm{CO}_{2}$ binary feed mixture was $9.96 \times 10^{-6}$ and that of $\mathrm{CO}_{2}$ was $1.21 \times 10^{-6} \mathrm{~mol} /\left(\mathrm{m}^{2} \mathrm{sPa}\right)$, respectively, at $300^{\circ} \mathrm{C}$. The sol-gel derived esterification based method explored in this study demonstrates that the zirconia membrane offers high potential for the purification of gas mixture at an elevated temperature.

\section{Acknowledgements}

This research has been funded by Higher Education Commission, Pakistan, for CUI, Abbottabad, through project No: 7816/Federal/ NRPU/R\&D/HEC/ 2017 and Research Deanship of University of Ha'il - Saudi Arabia through project number RG-191313".

\section{Conflict of Interest}

The authors declare that there is no conflict of interest regarding the publication of this manuscript.

\section{References}

1. KOROS W.J., MA Y.H., SHIMIDZU T. Terminology for membranes and membrane processes: Pure Appl. Chem. 68, 1479, 1996.

2. MEINEMA H.A., DIRRIX R.W.J., BRINKMAN H.W., TERPSTRA R.A., JEKERLE J., KOSTERS P.H. Ceramic Membranes for Gas Separation - Recent Developments and State of the Art: Interceram., 54, 2005.

3. LI W., DONG H., YU H., WANG D., YU H. Global characteristics and trends of research on ceramic membranes from 1998 to 2016: Based on bibliometric analysis combined with information visualization analysis: Ceramics International. 44, 6926, 2018.

4. GITIS V., ROTHENBERG, G. Ceramic membranes: new opportunities and practical applications: first ed, John Wiley \& Sons. 2016.

5. BUEKENHOUDT A. Stability of porous ceramic membranes: Membrane Science and Technology. 13, 1, 2008.

6. DASHTI A., ASGHARI M. Recent progresses in ceramic hollow-fiber membranes: Chembioeng Reviews. 2, 54, 2015.

7. PADAKI M., MURALI R.S., ABDULLAH M.S., MISDAN N., MOSLEHYANI A., KASSIM M.A., ISMAIL A.F. Membrane technology enhancement in oil-water separation: A review. Desalination. 357, 197, 2015.

8. FRAGA M.C., SANCHES S., PEREIRA V. J., CRESPO J.G., YUAN L., MARCHER J., BENAVENTE J. Morphological, chemical surface and filtration characterization of a new silicon carbide membrane: Journal of the European Ceramic Society. 37, 899, 2017.

9. CHEN L., MALFLIET A., ZHENG L., JONES P.T., BLANPAIN B., GUO M. Densification mechanism of porous alumina plugs by molten steel with different oxygen levels: Journal of the European Ceramic Society. 38, 2662, 2018.

10. ASAEDA M., YAMASAKI S. Separation of inorganic/organic gas mixtures by porous silica membranes: Separation and Purification Technology. 25, 151, 2001. 
11. LI L., QI H. Gas separation using sol-gel derived microporous zirconia membranes with high hydrothermal stability: Chinese Journal of Chemical Engineering. 23, 1300, 2015.

12. HONG Q.I. Preparation of composite microporous silica membranes using TEOS and 1, 2-bis (triethoxysilyl) ethane as precursors for gas separation: Chinese Journal of Chemical Engineering. 19, 404, 2011.

13. GUO F., LIU Y., WANG G., YI M., CAI H., WANG X., ZHAO X. Hydrothermal ageing of tetragonal zirconia porous membranes: Effect of thermal residual stresses on the phase stability: Corrosion Science. 142, 66, 2018.

14. KUMAR R.V., GHOSHAL A.K., PUGAZHENTHI G. Fabrication of zirconia composite membrane by in-situ hydrothermal technique and its application in separation of methyl orange: Ecotoxicology and environmental safety. 121, 73, 2015.

15. DA X., CHEN X., SUN B., WEN J., QIU M., FAN Y. Preparation of zirconia nanofiltration membranes through an aqueous sol-gel process modified by glycerol for the treatment of wastewater with high salinity: Journal of Membrane Science. 504, 29, 2016.

16. WANG C., LIU T., WANG X., LI J., JIN H., YU J., MO Y. A novel limiting current oxygen sensor prepared by slurry spin coating: Sensors and Actuators B: Chemical. 270, 518, 2018.

17. SON C., BHARDWAJ A., HONG J.W., KIM J.W., MOON H.S., NOH H.S., SONG S.J. Preparation and characterization of plasma-sprayed yttria stabilized zirconia as a potential substrate for NOx sensor: Ceramics International. 43, 4083, 2017.

18. ZHOU W., MA Z., GUO S., WANG M., WANG J., XIA M., ZHAO Y. Comparative study of $\mathrm{CO}$ adsorption on zirconia polymorphs with DRIFT and transmission FT-IR spectroscopy: Applied Surface Science. 427, 867, 2018.

19. MAJEDI A., DAVAR F., ABBASI A. Citric acidsilane modified zirconia nanoparticles: Preparation, characterization and adsorbent efficiency: Journal of environmental chemical engineering. 6, 701, 2018.

20. XIA W., WANG F., MU X., CHEN K., TAKAHASHI A., NAKAMURA I., FUJITANI T. Highly selective catalytic conversion of ethanol to propylene over yttrium-modified zirconia catalyst: Catalysis Communications. 90, 10, 2017.

21. OLOYE F.F., ALIYEV R., ANDERSON J.A. Hydroisomerisation of n-heptane over Pt/sulfated zirconia catalyst at atmospheric pressure: Fuel. 222, 569, 2018.

22. MADON R.J., NAGEL P., THAKUR D.S. Copper-zirconia catalyst and method of use and manufacture: U.S. Patent. 9, 868, 2018.

23. CIESIELCZYK F., GOSCIANSKA J., ZDARTA J., JESIONOWSKI T. The development of zirconia/silica hybrids for the adsorption and controlled release of active pharmaceutical ingredients: Colloids and Surfaces A: Physicochemical and Engineering Aspects. 545, 39, 2018.

24. GAGLIERI C., ALARCON R.T., DE GODOI MACHADO R., PADOVINI D.S., PONTES F.M., CAIRES F.J. Thermal study of $\mathrm{ZrO}_{2}$ nanoparticles: Effect of heating and cooling cycles on solid-solid transition: Thermochimica Acta. 653, 59, 2017.

25. SHAH S.H., UEMURA Y., YUSUP S., KUSAKABE K., MAHMOOD Q., ALI A. Nano-structured porous yttriastabilized zirconia membrane for high-temperature $\mathrm{CO}_{2}$ capture from $\mathrm{H}_{2} / \mathrm{CO} 2$ mixture: Arab. J. Sci. Eng., 41, 4763, 2016.
26. LAWAL S., KANEZASHI M., NAGASAWA H., TSURU T. Development of an acetylacetonate-modified silica-zirconia composite membrane applicable to gas separation: Journal of Membrane Science. 599, 117844, 2020.

27. DA SILVA D.G., VASCONCELOS W.L. Cerâmica Effect of sol-gel processing parameters on structure of zirconia: Ceramica. 65, 17, 2019.

28. LI S., WEI C., ZHOU L., WANG P., MENG Q., XIE Z. Sol-gel derived zirconia membrane on silicon carbide substrate: Journal of the European Ceramic Society. 39, 3804, 2019.

29. KATSUKI K., SAKAMOTO S., SAIE T., MOROOKA S. Pore structure of silica membranes formed by a sol-gel technique using tetraethoxysilane and alkyltriethoxysilanes: Sep. Purif. Technol., 16, 139, 1999.

30. KIM Y.S., KUSAKABE K., MOROOKA S., YANG S.M. Preparation of microporous silica membranes for gas separation: Korean. J. Chem. Eng., 18, 106, 2001,

31. LU Q., DINIZ DA COSTA C., DUKE M., GIESSLER S., SOCOLOW R., WILLIAMS H., KREUTZ T. Inorganic membranes for hydrogen production and purification: A critical review and perspective. J. Colloid Interface. Sci., 314, 589, 2007,

32. SPILLMAN R.M. Economics of gas separation membranes Chem: Eng. Pro., 85, 41, 1989,

33. GU Y., KUSAKABE K., MAROOKA S. Sulphuric acid-modified zirconia membrane for use in hydrogen separation: Sep. Purif. Technol., 24, 489, 2001.

34. CHANG C.H., GOPALAN R., LIN Y.S.A. Comparative study on thermal and hydrothermal stability of alumina, titania and zirconia: J. Membr. Sci., 182, 27, 1994.

35. GU Y., KUSAKABE K., MOROOKA S. Effect of chelating agent 1, 5 diaminopentane on the microstructures of sol-gel derived zirconia membranes: Sep. Sci. Technol., 36, 3689, 2001.

36. WU J.C.S., CHENG L.C. An improved synthesis of ultrafiltration zirconia membranes via the sol-gel route using alkoxide precursor: J. Membr. Sci., 167, 253, 2000.

37. OKUBO T., TAKAHASHI T., SADAKATA M., NAGAMOTO, H. Crack free porous YSZ membrane via controlled synthesis of zirconia sol: J. Membr. Sci., 118, $151,1996$.

38. LARBOT A., FABRE J.P., GUIZARD C., COT L. Inorganic membranes obtained by sol-gel technique: J. Membr. Sci., 39, 203, 1988.

39. KIM S.G., NAM S.W., HYUN S.H. Sol-gel processing of yttria stabilized zirconia film derived from zirconium-nbutoxideacetic acid-nitric acid-water-isopropanol system. J. Membr. Sci. 39, 2683, 2004.

40. SHI L., TIN K.C., WONG N.B. Thermal stability of zirconia membranes: J. Membr. Sci., 34, 3367, 1999.

41. AHN S.J., TAKAGAKI A., SUGAWARA T., KIKUCHI R., OYAMA S.T. Permeation properties of silica-zirconia composite membranes supported on porous alumina substrates: Journal of Membrane Science. 526, 409, 2017.

42. KUSAKABE K., FUMIO S., EDA T., ODA M., SOTOWA K.I. Hydrogen production in zirconia membrane reactors for use in PEM fuel cells: Int. J. Hydrog. Energy., 30, 989, 2005.

43. KIM J., LIN Y.S. Synthesis and characterization of yttria stabilized zirconia membranes: J. Membr. Sci., 139, 75, 1998. 